$\begin{gathered}\text { Науковий вісник НЛтУ України } \\ \text { Scientific Bulletin of UNFU } \\ \text { https://nv.nltu.edu.ua }\end{gathered}$
$\begin{array}{r}\text { https://doi.org/10.36930/40300517 } \\ \text { Article received 03.11.2020 p. } \\ \text { Article accepted 22.10.2020 p. } \\ \text { UDC }\end{array}$

В. В. Жуковський, С. В. Шатний, Н. А. Жуковська

Національний університет водного господарства та природокористування, м. Рівне, Україна

\title{
НЕЙРОННА МЕРЕЖА ДЛЯ РОЗПІЗНАВАННЯ ТА КЛАСИФІКАЦІЇ КАРТОГРАФІЧНИХ ЗОБРАЖЕНЬ ГРУНТОВИХ МАСИВІВ
}

\begin{abstract}
Запропоновано нейронну мережу для розпізнавання картографічних зображень грунтових масивів та класифікації ландшафтних ділянок за типами грунтових масивів із використанням нейронної мережі. Описано підходи до проектування архітектури, методів навчання, підготовки даних для проведення навчання, тренування та тестування нейронної мережі. Розроблено структурно-функціональну схему нейронної мережі, яка складається із вхідного, прихованих та вихідного шарів, кожен окремий нейрон описано відповідною активаційною функцією із підібраними ваговими коефіцієнтами. Показано доцільність застосування кількості нейронів, їх тип та архітектуру для проведення задачі розпізнавання та класифікації ділянок на кадастрових картах. Як вихідні дані використано відкриті державні інформаційні ресурси, в яких виділено окремі ділянки за типами грунтів, їх поширення та сформовано базу даних для навчання та тренування нейронної мережі. Проаналізовано ефективність, швидкодію та точність роботи нейронної мережі, зокрема, проведено комп'ютерну симуляцію із використанням сучасного програмного забезпечення та математичне моделювання обчислювальних процесів у середині структури нейронної мережі. Розроблено програмні засоби для попередньої підготовки та оброблення вхідних даних, подальшого тренування та навчання нейронної мережі та безпосередньо процесу розпізнавання та класифікації. Відповідно до отриманих результатів, розроблена модель та структура нейромережі, іiі програмні засоби реалізації показують високу ефективність як на етапі попереднього оброблення даних, так і загалом на етапі класифікації та виділення цільових ділянок грунтових масивів. Надалі наступним етапом досліджень $є$ розроблення та інтеграція програмно-апаратної системи на основі розпаралелених та частково розпаралелених засобів обчислювальної техніки, що дасть змогу значно пришвидшити обчислювальні операції, досягти виконання процесів навчання та тренування нейронної мережі в режимі реального часу та без втрати точності. Подані наукові та практичні результати мають високий потенціал для інтеграції в сучасні інформаційно-аналітичні системи, системи аналізу та моніторингу за станом навколишнього середовища, технологічними об'єктами та об'єктами промисловості.
\end{abstract}

Ключові слова: метод навчання; засіб тестування; збіжність пошукового процесу; нейрон; активаційна функція; ваговий коефіцієнт.

\section{Вступ}

Розвиток технічних і програмних засобів сприяють появі нових способів опрацювання даних для прийняття ефективних рішень. Зокрема, у сільському господарстві однією з ресурсозберігаючих технологій є точне землеробство (англ. Precision Agriculture) [11]. Ця технологія дає змогу розділяти велику ділянку на декілька менших зон управління. Ці зони можуть бути розділені за різними класифікаційними ознаками: тип грунту, вологість, наявність шкідників, показник NDVI тощо. Використання точного землеробства забезпечує набагато більший економічний ефект, дає змогу точніше змоделювати майбутній стан грунтового масиву, підвищити відтворення родючості та рівень екологічної чистоти сільськогосподарської продукції $[2,3]$.

Географічні карти мають велике практичне і наукове значення. Розвиток картографії завжди визначався потребами життя. Починаючи зі шкільних років, карта знайома кожній людині. Вона - повсякденне явище в нашому житті. Але саме ця щоденність нерідко приводить до спрощеного погляду на карту, іiі недооцінки, неповному використанню закладених у ній можливостей. Важливо не тільки мати добру карту, але і вміти працювати 3 нею, максимально використовуючи всі іï можливості. Тому розробка питань використання карт належить до найважливіших проблем картографії, а розпізнавання та класифікації картографічних зображень грунтових масивів $є$ актуальним дослідженням. Це також пов'язано з тим, що останнім часом для розпізнавання картографічних зображень грунтових масивів i класифікації ландшафтних ділянок широко застосування отримали нейронної мережі.

Об'єкт дослідження - оброблення та аналіз картографічних зображень.

Інформація про авторів:

Жуковський Віктор Володимирович, канд. техн. наук, доцент, кафедра комп'ютерних наук та прикладної математики. Email: v.v.zhukovskyi@nuwm.edu.ua; https://orcid.org/0000-0002-7088-6930

Шатний Сергій В'ячеславович, ст. викладач, кафедра обчислювальної техніки. Email: serhii.shatnyi@gmail.com

Жуковська Наталія Анатоліївна, канд. техн. наук, доцент, кафедра комп'ютерних наук та прикладної математики. Email: n.v.zhukovska@nuwm.edu.ua; https://orcid.org/0000-0001-7839-0684

Цитування за ДСтУ: Жуковський В. В., Шатний С. В., Жуковська Н. А. Нейронна мережа для розпізнавання та класифікації картографічних зображень ґрунтових масивів. Науковий вісник НлТУ України. 2020, т. 30, № 5. С. 100-104.

Citation APA: Zhukovskyy, V. V., Shatnyi, S. V., \& Zhukovska, N. A. (2020). Neural network for recognition and classification of soil massifs mapping. Scientific Bulletin of UNFU, 30(5), 100-104. https://doi.org/10.36930/40300517

100 Науковий вісник НЛТУ України, 2020, т. 30, № $5 \quad$ Scientific Bulletin of UNFU, 2020, vol. 30, no 5 
Предмет дослідження - методи, моделі, структурно-функціональні схеми організації штучних нейронних мереж, які дають змогу здійснити оброблення картографічних зображень грунтових масивів для подальшого їх розпізнавання та класифікації, а також визначення приналежності до певного класу.

Мета роботи - розроблення нейронної мережі для розпізнавання та класифікації картографічних зображень грунтових масивів, призначеної для підвищення точності та швидкості аналізу грунтових масивів.

Для досягнення зазначеної мети визначено такі основні завдання дослідження:

- проаналізувати сучасні методи оброблення та аналізу картографічних зображень;

- удосконалити метод попереднього оброблення даних внаслідок використання штучних нейронних мереж;

• розробити архітектуру нейронної мережі, методи іiі навчання та тренування.

Наукова новизна отриманих результатів дослідження:

- удосконалено метод попереднього оброблення даних для штучної нейронної мережі способом нормування масиву вхідної інформації, що дало змогу підвищити швидкість оброблення даних;

• розроблено архітектуру штучної нейронної мережі для проведення процедури розпізнавання та класифікації картографічних зображень, що забезпечує підвищення точності розпізнавання образів i, завдяки використанню ітераційного методу навчання, скорочує загальний час на таку роботу.

Практична значущість результатів дослідження:

- застосування для попереднього оброблення даних нейромережевих методів нормування дає змогу зменшити загальна тривалість оброблення картографічних даних більше ніж на $20 \%$;

- використання методу класифікації картографічних зображень за допомогою нейронної мережі дає змогу підвищити точність визначення ділянок із різними типами грунтів до $73 \%$.

Аналіз останніх досліджсен та публікацій. Результати здійснених досліджень показують, що точне землеробство є одним із найбільших ринків для комерційних безпілотних літальних апаратів (БПЛА) [4]. Безпілотники дають змогу швидше отримати загальну картину поля, на відміну від традиційного способу огляду поля легковими автомобілями. Однак до недоліків технології точного землеробства варто віднести копітку роботу зі збирання та аналізу даних, а також те, що технологія все ще розвивається, і тому потрібно уважно ставитися до автоматичних рекомендацій [14]. Зокрема, науковці передбачають, що із розвитком БПЛА покращаться методи оброблення зображень, польоти будуть тривати менше, з'являться кращі батареї та камери [8]. Окрім цього, науковцям потрібно акцентувати свою увагу на хемометричних або спектральних декомпозиційних методах аналізу, оскільки просторова і спектральна роздільна здатність систем гіперспектрального зондування зараз розвинулися достатньо для точного землеробства [9].

Робота над розпізнаванням областей картографічних зображень грунтових масивів та їх подальша класифікація $\epsilon$ важливою задачею. Багато вітчизняних учених працюють над подібними задачами розпізнавання будівель [3], аналізу та оцінювання забруднення грунтових масивів [5], оцінювання вологості грунту [12, 13] та ідентифікації сільськогосподарських культур [6] за допомогою супутникових знімків. Однак ці дослідження не відображають вирішення проблеми швидкодіючого оброблення даних великих об'ємів, що унеможливлює масштабування та інтеграцію 3 наявними системами [1]. Тому розпізнавання та класифікація картографічних зображень грунтових ділянок $\epsilon$ актуальною та важливою для вирішення задачею [7].

\section{Результати дослідження та їх обговорення}

1. Попереднс оброблення даних. Розглянемо практичні аспекти підготовки та попереднього оброблення даних, тренування та тестування нейронної мережі. Теоретичні та практичні підходи не є взаємовиключними, тому основним підходом є поєднання фундаментальних принципів нейромережевих технологій 3 практичним застосуванням. На рис. 1 зображено процес функціонування нейронної мережі.

\begin{tabular}{|c|c|c|}
\hline $\begin{array}{l}\text { 3бір та попереднє } \\
\text { оброблення даних }\end{array}$ & $\begin{array}{c}\epsilon \\
\mathrm{x}\end{array} \rightarrow\left[\begin{array}{c}\text { Вибір архітектури } \\
\text { мережі }\end{array}\right.$ & $\rightarrow \begin{array}{c}\text { Вибір алгоритму } \\
\text { навчання }\end{array}$ \\
\hline & $\begin{array}{c}\text { Аналіз продуктивності } \\
\text { мережі }\end{array}$ & $\begin{array}{l}\text { Еавчання } \\
\text { мережі }\end{array}$ \\
\hline
\end{tabular}

Рис. 1. Структурно-функціональна схема процесу функціонування нейронної мережі

Отже, навчання - це ітеративний процес, що починається із накопичення даних та попереднього оброблення для якіснішого процесу тренування. На цьому етапі дані повинні бути поділені на тренувальні, еталонні та тестувальні набори. Після вибору відповідного набору даних потрібно вибрати затребуваний тип мережі (багатошарова, динамічна і т.ін) та архітектуру (кількість шарів, кількість нейронів). Після цього вибираємо алгоритм тренування, який підходить для нейронної мережі та заданої проблеми.

Після навчання мережі потрібно проаналізувати продуктивність мережі. Цей аналіз може показати всі наявні проблеми із даними, архітектурою мережі або алгоритмом навчання. Цей процес $є$ ітеративним допоки продуктивність розробленої мережі не вийде на бажаний та наперед заданий рівень.

1.1. Процес попереднього навчання. На цьому етапі групуються задачі на три категорії: 1. Вибір даних; 2. Попереднє оброблення даних; 3. Вибір типу мережі та архітектури. Загалом дуже складно передати накопичені дані та правила безпосередньо у нейронну мережу, проте якість розробленої нейронної мережі буде настільки високою, наскільки якісно підготовлені дані для iii навчання. Навчальні дані повинні охоплювати повний діапазон вхідного простору, для якого нейронна мережі буде використовуватись. Неможливо гарантувати продуктивність нейромережі, коли входи із даними виходять за межі тренувального набору. Оскільки запропонована нейронна мережа для класифікації є нелінійною "чорною скринею", вона не здатна до якісної екстраполяції результатів. Також не можна бути певними, що вхідний простір даних відповідає тренувальному набору. Запропонована конструкція нейронної мережі для вирішення простої задачі, для якої вхідний вектор є малої розмірності і кожен елемент вхідного вектора може бути вибраний незалежно від індексації, дає змогу оперувати вхідним простором як сіткою. Для багатьох задач, зокрема і класифікації картографічних зображень, 
розмірність вхідного простору є великою, що унеможливлює та ускладнює процес абстрактного представлення даних. У такому випадку всі дані вхідних наборів $\epsilon$ залежними. Абстрактне зображення тестового набору даних наведено на рис. 2.

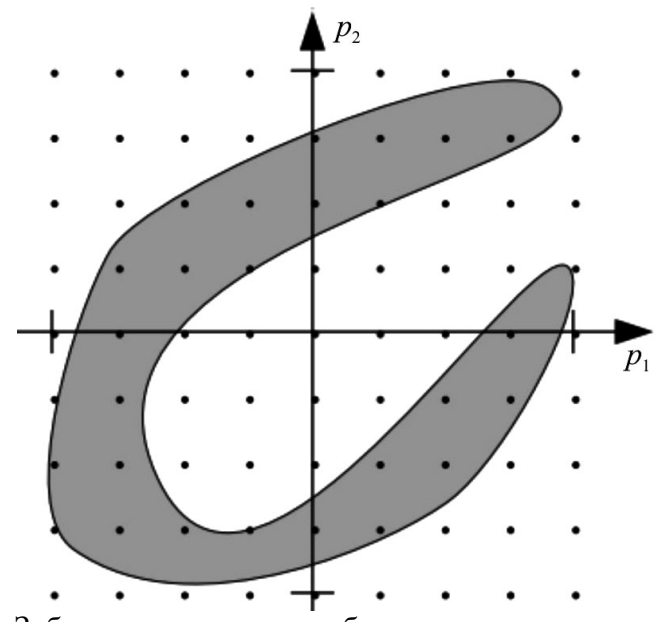

Рис. 2. Зображення тестового набору даних

Виділена область представляє діапазон [-1;1]. У цьому випадку робота мережі зводиться до знаходження функції опису виділеної області даних. Пошук функції для визначення даних з-за межі виділеної області не проводиться, оскільки це не входить до задачі класифікації, підвищує складність мережі та сповільнює загальна тривалість функціонування мережі. Бувають випадки визначення виділеної області із недостатньою точністю, похибка зворотного поширення процесу навчання мережі зростає, цим самим зменшуючи точність процесу класифікації та виходу пошукового процесу за бажану область набору даних. У цьому випадку необхідно провести попередню обробку вхідного набору даних, використовуючи традиційні методи обчислення. Способом аналізу навченої нейронної мережі можна зробити висновок про адекватність процесу навчання та відповідно отриманих результатів у майбутньому. Додатково використовуються методи, що дають змогу ідентифікувати вихід пошукового процесу за межі виділеної області наборів даних, на яких відбувався процес навчання та тренування. Цей підхід не підвищує продуктивності мережі, однак він унеможливить використання мережі в задачах, для яких вона $є$ непристосованою.

Після процедури збирання та підготовки даних, всі набори поділяються на три групи: 1) тренувальна група; 2) група валідації; 3) тестувальна група. Під час вирішення задачі класифікації картографічних зображень було визначено, що тренувальний набір займає $70 \%$ всього об'єму, набір для валідації - 15 \%, набір тестування - $15 \%$. Варто зазначити, що об'єм кожної групи може різнитись залежно від задачі та типів даних. Застосований метод поділу цілого об'єму даних на групи полягає у довільному виборі даних із початкового набору підготовлених даних. Дослідним шляхом підтверджено, що цей метод гарантує задовільний результат відповідно швидкодії, але в подальшому для збільшення точності необхідно ввести класифікаційні коефіцієнти. Також цей підхід можливо використати під час аналізу процесу навчання/тренування для визначення проблем після розділення даних.

1.2. Попереднє оброблення даних. Основна мета попереднього оброблення даних - спростити навчання ме- режі та провести початкову обробку наборів даних. Попереднє оброблення даних складається з таких етапів: нормування, виокремлення ознак, заповнення відсутніх значень. Запропонований метод нормування даних полягає в тому, що весь діапазон даних повинен потрапити у стандартизований діапазон, "зрозумілий" нейронній мережі. Для цього використаємо таку формулу:

$$
P^{n}=2 \cdot \text { Fun }\left(\frac{p^{m}-p^{\min }}{p^{\max }-p^{\min }}\right)-1,
$$

де: $p^{\min }-$ вектор, що містить мінімальні значення кожного елемента вхідного вектора; $p^{\max }$ - максимальні значення; $\operatorname{Fun}()$ - функція, яка здійснює поелементне ділення двох векторів; $p^{m}-$ нормалізований вхідний вектор.

У доповнення до процесу нормування, який містить лінійне перетворення, нелінійні перетворення часто виконуються як етап попереднього оброблення. На відміну від нормування, що є стандартною процедурою та може бути застосовною до будь-якого набору даних, запропоноване нелінійне перетворення може бути застосовне виключно до задачі класифікації картографічних зображень та із наперед підготовленими даними.

1.3. Виокремлення ознак. Метод виокремлення ознак використовується за умови, коли розмірність рядка вхідного вектора $є$ надлишковою та зайвою. Основна мета застосування цього методу - у зменшенні розмірності вхідного простору способом визначення властивостей кожного вектора та в подальшому використовувати ці властивості як одним із входів нейронної мережі. Для задачі класифікації картографічної ділянки, яка $\epsilon$ криволінійною, не потрібно визначати окремі просторові впадини, достатньо на етапі попередньої підготовки даних визначити їх кількість та подати числове значення на вхід нейронної мережі.

2. Проектування архітектури нейронної мережі. Наступним кроком після процесу навчання $\epsilon$ розроблення архітектури мережі. Базовий тип нейромережевої архітектури визначаємо за типом задачі, яку ми вирішуємо. Одразу після визначення архітектури, необхідною умовою $є$ задавання ознак архітектури, зокрема кількість нейронів та шарів, кількість входів та виходів та тип нейронних активаційних функцій.

Поставлену задачу класифікації картографічних зображень грунтових масивів можна подати як комбінацію відомих задач, зокрема розпізнавання образів та кластеризацію. Загалом задача зводиться до класифікації вхідних даних відповідно до цільових категорій. Відомо, що оптимальними для вирішення цієї задачі є багатошарові персептрони із передаточними функціями в ролі вихідного шару мережі. Після проведення аналізу та підготовки даних виявлено в ролі вихідного шару та вихідних нейронів застосувати сигмоїдні активаційні функції. Задача кластеризації або сегментації зводиться до групування вхідних даних відповідно до їхньої подібності. Відповідно до (літ) доцільним є застосування рекурентних та самоорганізованих карт, основною перевагою яких $\epsilon$ можливість візуалізувати багатовимірні простори.

На рис. 3 подано розроблену архітектуру нейронної мережі. В основі мережі знаходяться тангенційно-сигмоїдні передаточні функції на обох рівнях, що $\epsilon$ стандартом для нейромережі для задачі класифікації та розпізнавання образів. Можливим $є$ використання двох 
прихованих шарів, але дослідним шляхом встановлено, для розпізнавання та класифікації двовимірних зображень грунтових масивів достатньо одного прихованого шару. Кількість нейронів у прихованому шарі $S^{1}$ залежить від складності правил приналежності та визначається на етапі тестування та тренування мережі.

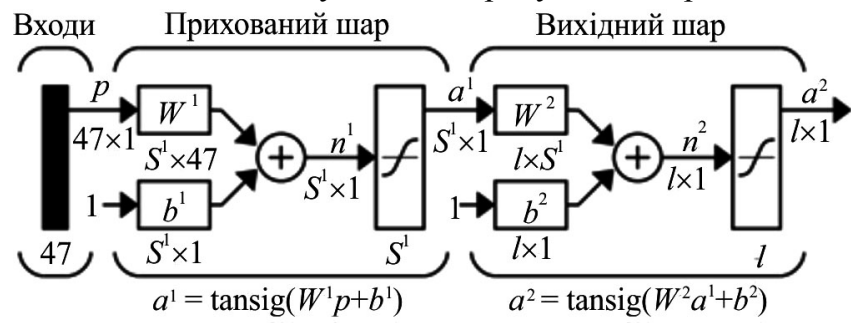

Рис. 3. Архітектура нейронної мережі

4. Комп'ютерна симуляція та аналіз результатів. Навчання мережі здійснювалось 3 використанням масштабованого градієнта, що $є$ ефективним засобом у задачі розпізнавання образів та класифікації. На рис. 4 зображено графік зміни середньоквадратичної похибки порівняно з числом ітерацій обчислювального процесу.

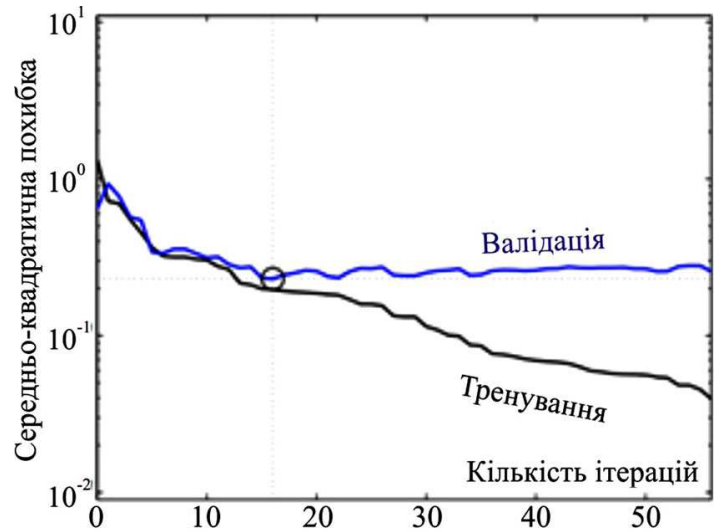

Рис. 4. Залежність середньоквадратичної похибки від кількості ітерацій

Використовується мережа із 10 нейронами у прихованому шарі $\mathrm{S}^{1}=10$. Мінімальне значення похибки отримано на шістнадцятому ітераційному процесі (див. рис. 4), і значення вагових параметрів нейронної мережі були збережені в цій точці. Як видно, похибка навчання не змінювалась впродовж наступних сорока ітерацій, тому процес навчання та тренування був зупинений.

Результати тренування зображено на рис. 5, $a$ у вигляді матриці збігів навченої нейронної мережі на даних тестування. На цьому рисунку зображена верхня ліва комірка показує 13 з 14 коректно класифікований грунтових кластерів, комірка 2,2 відображає 66 з 71 коректно класифікованих взірців. Найбільша кількість помилково класифікованих взірців відображена в комірці 1,2.

\begin{tabular}{|c|c|c|}
\hline $1 \mid \begin{array}{c}13 \\
15.3 \%\end{array}$ & $\begin{array}{c}5 \\
5.9 \%\end{array}$ & $\begin{array}{l}72.2 \% \\
27.8 \%\end{array}$ \\
\hline $1.2 \%$ & $\begin{array}{c}66 \\
77.6 \%\end{array}$ & $\begin{array}{c}98.5 \% \\
1.5 \%\end{array}$ \\
\hline $92.9 \%$ & $93.0 \%$ & $92.9 \%$ \\
\hline $7.1 \%$ & $7.0 \%$ & $7.1 \%$ \\
\hline
\end{tabular}

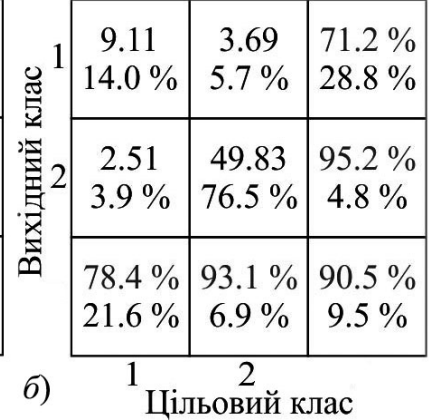

Рис. 5. Матриця збігів процесу тестування $(a)$ та усереднені значення процесу симуляції методом Монте-Карло (б)
Додатково проведено аналіз якості розпізнавання шляхом отриманої операційної характеристики (ROC). На рис. 6 відображено графік ROC для даних тестування. Ідеальна траєкторія шляху ROC проходить крізь комірки 0,0-0,1-1,1

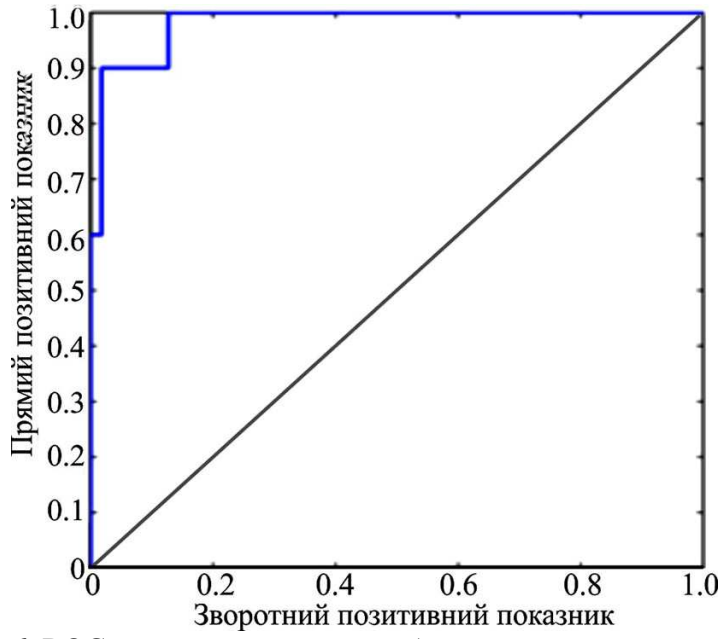

Pис. 6. ROC характеристика для набору тестувальних даних

Результати, відображені на рис. 5, $a$ та 6 , показують розподіл даних на тренувальні/тестувальні/перевірочні набори. Наступним етапом аналізу є визначення чутливості результатів шляхом проведення симуляції методом Монте-Карло. Дані були розділені на 1000 різних часових проміжків, що відповідає динамічній зміні наборів даних об'єкта симуляції. Для кожного розподілу даних, навчання нейронної мережі відбувалось із довільними ваговими коефіцієнтами. Результати симуляції були усереднені та зведені до таблиці (рис. 5,б).

Результати відображають дані класифікації наборів даних для 12 класів грунтів на кожен окремий набір даних. Виходячи із результатів, більше 9 класів були визначені коректно, при цьому середньоквадратична похибка не перевищує значення 9,5 \%. Усереднені результати симуляції методом Монте-Карло є подібними до отриманих оригінальних результатів. На рис. 7 відображено гістограму відхилення похибки. Середнє значення похибки становить 9,5\%, середнє значення відхилення - 3,5\%.

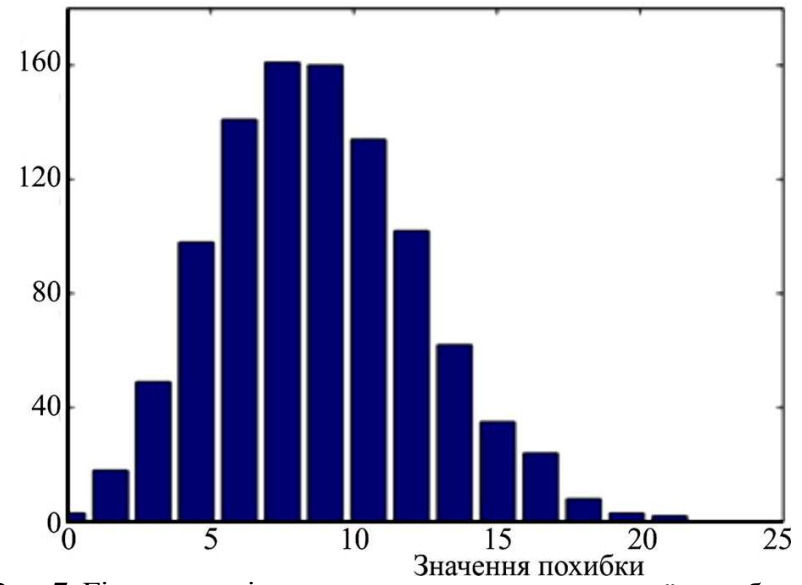

Рис. 7. Гістограма відхилення середньоквадратичної похибки

\section{Висновки}

У роботі розглянуто актуальні питання розроблення та застосування штучних нейронних мереж у системи точного землеробства. Застосування подібних методів та алгоритмів дає змогу підвищити ефективність та точність опрацювання даних та їх подальше оброблення. 
Розроблено структурно-функціональну схему та архітектуру штучної нейронної мережі, в якій за рахунок оптимальних активаційних функцій нейронів, вдалося підвищити точність розпізнавання картографічних зображень грунтів до $73 \%$.

Розроблено метод попереднього оброблення та підготовки даних, що дає змогу підвищити швидкодію роботи мережі на 20 \% порівняно 3 наявними підходами та забезпечує нормування вхідних даних для подальшого навчання та тренування. Проведено комп'ютерні симуляції режимів тестування та тренування штучної нейронної мережі, визначено крайові умови функціонування та оптимальний режим навчання по швидкодії та тривалості.

Підтверджсеня. Публікація містить результати наукових досліджень, проведених у рамках науково-технічної розробки Міністерства освіти і науки України "Інформаційно-аналітична система органічного землеробства та забезпечення екологічної стійкості грунтів" (№ ДР0120U000235).

\section{References}

1. Carpenter, G. A., Grossberg, S., \& Rosen, D. B. (1991, Jun.) Fuzzy ART: fast stable learning and categorization of analog patterns by an adaptive resonance system. Neural Networks, 4(6), 759-771.

2. Cassman, K. G. (1999). Ecological intensification of cereal production systems: yield potential, soil quality, and precision agriculture. Proc Natl Acad Sci USA, 96, 5952-9. https://doi.org/10.1073/pnas.96.11.5952

3. Hnatushenko, V. V., Kavats, O. O., Halchenko, E. B., \& Kavats, Yu. V. (2016). Informatsiina tekhnolohiia rozpiznavannia budivel na bahatokanalnykh fotohrammetrychnykh zobrazhenniakh vysokoi prostorovoi zdatnosti na osnovi morfolohichnykh indeksiv. Visnyk Khersonskoho natsionalnoho tekhnichnoho universytetu, 195-198. [In Ukrainian].

4. Karpowicz, J. (2016). Above the field with UAVs in precision agriculture. Commercial UAV Expo: Las Vegas, NV, USA.

5. Kreta, D. L. (2016). Informatsiina tekhnolohiia analizu ta otsinky zabrudnennia skladovykh dovkillia. Matematychne modeliuvannia v ekonomitsi, 43-56. [In Ukrainian].

6. Lavreniuk, M., Kussul, N., \& Novikov, A. (2018). Deep Learning Crop Classification Approach Based on Sparse Coding of Time Series of Satellite Data. B: IGARSS 2018-2018 IEEE International Geoscience and Remote Sensing Symposium; 22.07.201827.07.2018; Valencia: IEEE; 22.07.2018-27.07.2018, 4812-4815. https://doi.org/10.1109/IGARSS.2018.8518263

7. Martnez-Zarzuela, M., Pernas, F., de Pablos, A., Rodrguez, M., Higuera, J., Giralda, D., \& Ortega, D. (2009). Adaptive Resonance Theory fuzzy networks parallel computation using CUDA. In Proc. 10th Int. Work-Conference. Art. Neural Networks, LNCS 5517, 149-156.

8. Mogili, U. R., \& Deepak, B. B. V. L. (2018). Review on Application of Drone Systems in Precision Agriculture. Procedia Computer Science. 133, 502-509. https://doi.org/10.1016/j.procs.2018.07.063

9. Mulla, D. J. (2013). Twenty five years of remote sensing in precision agriculture: Key advances and remaining knowledge gaps. Biosystems Engineering, 114, 358-371. https://doi.org/10.1016/j.biosystemseng.2012.08.009

10. Petro Skrypchuk, Viktor Zhukovskyy, Halyna Shpak, Nataliia Zhukovska, \& Halyna Krupko. (2020). Applied Aspects of Humus Balance Modelling in the Rivne Region of Ukraine. J. Ecol. Eng. 21, 42-52. https://doi.org/10.12911/22998993/123255

11. Pierce, F. J., \& Nowak, P. (1999). Aspects of Precision Agriculture. B: Advances in Agronomy (Vol. 67: Elsevier; 1-85. https://doi.org/10.1016/S0065-2113(08)60513-1

12. Romanchuk, I. F., Sakhatskyi, O. I., \& Apostolov, O. A. (2018). Otsinka volohosti gruntu za dopomohoiu suputnykovykh znimkiv Sentinel-2 (na prykladi Baryshivskoho polihonu Kyivskoi oblasti). Dopovidi NAN Ukrainy. [In Ukrainian].

13. Vlasyuk, A., Zhukovskyy, V., Zhukovska, N., Pinchuk, O., \& Rajab, H. (2020). Mathematical Modeling of Heat, Mass and Moisture Transfer in Catalytic Porous Media. WSEAS Transactions on Applied and Theoretical Mechanic, 15, 52-59. https://doi.org/10.37394/232011.2020.15.8

14. Zhang, N., Wang, M., \& Wang, N. (2002). Precision agriculture a worldwide overview. Computers and Electronics in Agriculture, $36,113-132$.

V. V. Zhukovskyy, S. V. Shatnyi, N. A. Zhukovska

National University of Water and Environmental Engineering, Rivne, Ukraine

\section{NEURAL NETWORK FOR RECOGNITION AND CLASSIFICATION OF SOIL MASSIFS MAPPING}

The paper presents the neural network for recognition and classification of cartographic soil massifs images. Some approaches to designing architecture, teaching methods, and data preparation for training, coaching and neural network testing are described. In the course of research the structural and functional scheme of the neural network is developed, which consists of the input, hidden and output layer, each individual neuron is described by the corresponding activation function with the selected weights. The expediency of using the number of neurons, their type and architecture for the task of recognizing and classifying areas on cadastral maps is shown. The open state information resources in which separate sites on types of soils, their distribution are allocated are used as initial data, and the database for training and training of a neural network is formed. The paper also provides the analysis of the efficiency, speed and accuracy of the neural network, in particular, a computer simulation using modern software and mathematical modeling of computational processes in the middle of the neural network. Software has been developed for preliminary preparation and processing of input data, further training and education of the neural network and directly the process of recognition and classification. According to the obtained results, the developed model and structure of the neural network, and its software tools show high efficiency both at the stage of preliminary data processing and in general at the stage of classification and selection of target areas of soil massifs. The next stage of research is the development and integration of software and hardware system based on parallel and partially parallel computer technology, which will significantly speed up computational operations, achieve the implementation of learning and training of the neural network in real time and without loss of accuracy. The presented scientific and practical results have a high potential for integration into existing information and analytical systems, systems of analysis and monitoring of the state of the environment, technological and industrial facilities.

Keywords: learning method; testing tool; search process convergence; neuron; activation function; weighting factor. 